\title{
COVID-19 and Asian Americans: How Elite Messaging and Social Exclusion Shape Partisan Attitudes
}

\author{
Nathan Kar Ming Chan, Jae Yeon Kim and Vivien Leung
}

\begin{abstract}
Extending theories of social exclusion and elite messaging, we argue that Trump's targeted rhetoric toward Asian Americans during the COVID-19 pandemic pushes the racial group, largely "Independent" or nonpartisan affiliated, to lean more towards the Democratic Party. We support this claim by combining social media (Study 1) and survey data (Study 2) analysis. Tracing 1.4 million tweets, we find that Trump's rhetoric has popularized racially charged coronavirus-related terms and that exclusionary, antiAsian attitudes have increased in the United States since the pandemic began. Next, by analyzing repeated cross-sectional weekly surveys of Asian Americans from July 2019 to May 2020 ( $n=12,907)$, we find that the group has leaned more towards the Democratic Party since Trump first made inflammatory remarks towards Asian Americans. Whites, Blacks, and Latina/os, on the other hand, exhibited fewer and less consistent changes in Democratic Party-related attitudes. Our findings suggest that experiences with social exclusion that are driven by elite sources further cement Asian Americans as Democrats.
\end{abstract}

$T$ he coronavirus pandemic, which originated in Wuhan, China, has spread throughout the world. Beginning in March 2020, California issued the first stay-at-home orders, with other states following suit. ${ }^{1}$ With widespread orders to stay-at-home and social distance in

A list of permanent links to Supplemental Materials provided by the authors precedes the References section.

*Data replication sets are available in Harvard Dataverse at: https://doi.org/10.7910/DVN/5DHYTU

Nathan Kar Ming Chan (1) is a National Science Foundation Graduate Research Fellow and Doctoral Candidate at the University of California, Irvine (nkchan@uci.edu). He studies group identity, public opinion, and political participation among minorities.

Jae Yeon Kim (1) is Assistant Research Scholar at the SNF Agora Institute at Johns Hopkins University (jkim638@jhu.edu). He studies power, inequality, and resistance among marginalized populations.

Vivien Leung (1) is Assistant Professor of Political Science at Bucknell University (vivien.leung@bucknell.edu). They study discrimination, behavior, and political psychology among minority populations. public spaces to help contain the spread, the pandemic has impacted the lives of everyone in the United States.

During the early stages of the pandemic, political elites such as former president Trump linked Asian Americans to the virus, resulting in an anti-Asian atmosphere characterized by social exclusion. Even though Trump had already made some connection between the coronavirus and China in January and February, he did this more explicitly in March 2020, as confirmed coronavirus cases in the United States began to surge that month. Trump doubled down on this rhetoric even after receiving criticism for his and his administration's early response to the pandemic, or lack thereof. Even though the World Health Organization (WHO) warns against naming or associating diseases with racial characteristics, ${ }^{2}$ Trump continued to use racialized COVID-19 terms. Subsequently, other members of the GOP (the Republican Party) followed suit. ${ }^{3}$ As a result, Trump strengthened the explicit association between the coronavirus to Chinese Americans, and this connection has also extended to non-Chinese Asian Americans as well.

The more explicit association of Asian Americans to the virus has come at a cost. Even though violence and racism against Asian Americans is not new, ${ }^{4}$ the coronavirus pandemic has brought forth a renewed wave of anti-Asian bias, which stems from elite-level associations of the virus with Asians. Across the country, Asian Americans have reported a surge in harassment and hate crimes on the basis 
of their race (Margolin 2020). The website Stop AAPI [Asian American Pacific Islander] Hate ${ }^{5}$ recorded nearly 1,500 incidents of anti-Asian hate incidents in one month (Jeung and Nham 2020). A year later, the same organization reported an increase totaling 3,795 anti-Asian hate incidents. These racist incidents are also not limited to Chinese Americans, but to other Asian Americans (such as Filipino, Thai, and Korean Americans) as well (Jeung et al. 2021). Racialized, targeted language by elites, such as calling groups a "disease" or a "cancer," violates norms of tolerance. When elites engage in this behavior, the mass public follows suit (Zaller 1992; Lenz 2013; Broockman and Butler 2017). We extend this work on elites' "emboldening effect" (Newman et al. 2019) to Asian Americans, particularly paying attention to how Trump's rhetoric creates an atmosphere where it is socially acceptable to express and act on anti-Asian sentiment.

We situate this project in the broader literature on elitedriven messaging, social exclusion, and Asian American partisanship. We examine how Trump's labeling of the virus as the "China virus" has contributed to anti-Asian sentiment in broader U.S. society, and how that messaging has also impacted Asian Americans' partisan attitudes. We argue that Trump's anti-Asian rhetoric, using the coronavirus as a driver, contributes to social exclusion of Asian Americans and pushes Asian Americans to lean more towards the Democratic Party. In a preview of our findings, we use Twitter data to track the spread of anti-Asian views in the United States. Analysis of 1.4 million tweets shows how Trump has racialized the public health crisis by popularizing racially charged COVID-19 terms such as the "Kung flu" and how anti-Asian attitudes have increased since the outbreak of COVID-19. We then utilize repeated, cross-sectional surveys over time to measure changes in partisan attitudes among Asian Americans as Trump and the GOP's rhetoric bears onward. Analysis of 12,907 Asian American survey respondents indicates that Trump's exclusionary rhetoric has motivated more favorability toward the Democratic Party. In contrast, these same partisan attitudes have not changed as much or as consistently for Whites, Blacks, and Latino/as. This lean toward the Democratic Party is important for a community that has been traditionally less likely to label themselves in partisan terms (Hajnal and Lee 2011; Wong et al. 2011). As Trump and other elites continue to consistently frame COVID-19 in anti-Asian terms, the social exclusion that Asian Americans encounter as a result may further cement this group with the Democratic Party.

\section{Elite Messaging, Social Exclusion, and Asian American Partisan Attitudes}

Elites and the frames, which they can elect to use, shape mass public opinion. This is the case when discussing various policy issues (Zaller 1992; Druckman 2001), particularly when it comes to welfare (Rose and
Baumgartner 2013; Schneider and Jacoby 2005; Gilens 1999), healthcare (Tesler 2012), and immigration (Haynes, Merolla, and Ramakrishnan 2016; Pérez 2015). Although norms of equality have made racial "dog whistles" and explicit racial appeals socially undesirable (Mendelberg 2001; Valentino, Hutchings, and White 2002), there has been a notable increase in the usage of inflammatory racially charged rhetoric by Trump and the Republican Party within the last few years (Costello 2016). Trump's provocations have been found to embolden supporters to act on their racial prejudices. For example, Trump's Twitter usage corresponded with an increase in anti-Muslim hate crimes in 2016 (Müller and Schwarz 2020). Additionally, through a series of experiments, Newman et al. (2019) find that exposure to racist elite speech regarding Latino immigrants increases the likelihood of an individual acting on their prejudices and engaging in discriminatory interpersonal acts. This "emboldening effect" occurs when political elites embrace racism and bias; this is a clear example of how elite racist rhetoric encourages discriminatory behavior at the mass level.

Asian Americans also present an interesting puzzle in the study of partisanship. At a superficial level, many Asian Americans have high median incomes, tend to identify as Evangelical Christians, or immigrated to the United States fleeing communism, traits which are typically associated with voting Republican (Gelman, Kenworthy, and $\mathrm{Su}$ 2010; Gelman 2010). 6 Despite these traits, Asian Americans have trended Democratic in the last few election cycles-65\% voted for Hillary Clinton in 2016 and $73 \%$ voted for Barack Obama in 2012. In comparison, only about $31 \%$ of Asian Americans voted for Bill Clinton in 1992 (Fuchs 2016). For the most recent presidential election, Ghitza and Robinson (2021) estimate that 67\% of AAPIs voted for the Democratic candidate. This preference for the Democratic Party, despite traditionally Republican predispositions, may be due to perceptions of Republicans as ideologically extreme, liberalizing peerto-peer socialization at school, and a preference for living in liberal urban areas in the United States (Raychaudhuri 2018, 2020).

Despite a tendency to vote for Democrats, Asian Americans are not as likely to explicitly identify with a party. Instead, a significant proportion of Asian Americans prefer to list themselves as "Independent" or "nonpartisan" (Hajnal and Lee 2011; Wong et al. 2011). Partisan identification is important because individuals who identify with a party are much more likely to vote than those who are unaffiliated (Campbell et al. 1960, 1966). Taken together, partisan preferences among Asian Americans are less stable relative to those of Whites and African Americans. If experiences with coronavirus-related exclusion, which stem from elite rhetoric, lead Asian Americans to be more solidified in their partisan 
identification, this may contribute to increased political participation and civic engagement at the polls and beyond. $^{8}$

We also aim to focus specifically on the experiences of Asian Americans during times of pandemic. Anti-Asian sentiment has been present in the United States since the late nineteenth century, and animosity towards Asian Americans is not new (Kim 1999; Junn 2007). Historically, Asian Americans were thought of as economic and cultural invaders to the U.S., a fear known as the "yellow peril." This fear contributed to racially motivated murders, lynching, and racist legislation such as the Page Act and Chinese Exclusion Act (Nguyen, Carter, and Carter 2019). In addition, Asian Americans were also thought to be disease-bearing, unsanitary, and the cause of outbreaks on the West Coast (Trauner 1978). This association of Asian Americans with disease resurfaced in the 2002-2004 severe acute respiratory syndrome (SARS) outbreak and recently during the COVID-19 pandemic, with popular news media associating outbreaks with "unsanitary wet markets" and the consumption of "bats, snakes, and dogs." "This plays into long-standing associations of Asians and Asian Americans as foreign and diseased. In the present day, Asian Americans are thought of as "competent" yet "cold" individuals who are stereotyped as intelligent and high achieving, yet non-American and unassimilable (Zou and Cheryan 2017; Fiske 2018; Cheryan and Monin 2005). Despite the pervasive stereotype of Asian Americans as "near White" or the "model minority," COVID-19 has laid bare the perpetual alienness of Asian Americans (Hua and Junn 2021).

According to the Pew Research Center, Asian Americans are also more likely to note that they are targets of discrimination than Latina/os and Whites (Budiman and Ruiz 2021). Some have found that discrimination, whether personally experienced or inflammatory rhetoric communicated by leaders, influences various political behavior outcomes and beliefs (Leung and Song 2021; McClain et al. 2009; Oskooii 2018; Newman et al. 2019). We further argue within this line of scholarship that Trump's racialized rhetoric contributes to a climate of social exclusion for Asian Americans. As Newman et al. (2019) find, Trump's racist rhetoric emboldens supporters to act upon prejudiced beliefs, which would have otherwise been seen as socially undesirable. The COVID-19 pandemic has also come with a staggering increase in antiAsian hate crimes, vandalism, and harassment (Jeung et al. 2021; Wong 2021; Tessler, Choi, and Kao 2020; see also Arora and Kim 2020). The perception of Asian Americans as foreigners makes it easy to justify anti-Asian attitudes and blame Asian Americans for "importing" the coronavirus $^{10}$ (Liu 2020). Taken together, we argue that inflammatory elite rhetoric contributes to very salient societal exclusion of Asian Americans during the coronavirus pandemic.
Further, these feelings of social exclusion have unique consequences on the partisan leanings of Asian Americans. The concept of social exclusion draws from groupbased (i.e., societal) and individual (i.e., psychological) work wherein individuals who are rejected or excluded by society associate exclusion with certain political groups. Evidence has shown that individuals generally view the Democratic Party as more favorable towards minorities (Carmines and Stimson 1989; Hajnal and Horowitz 2014). Even if minority individuals do not feel wholly included in the Democratic Party, they are aware that the Republican Party excludes them on the basis of their racial and ethnic group membership. As experienced on an interpersonal level, social exclusion leads Asian Americans to be more favorable towards the Democratic Party (Kuo, Malhotra, and Mo 2017). The Republican Party has also become increasingly viewed as ethnocentric and catering to White Americans (Kinder 2013). Thus, this ethnocentrism leads Asian Americans, who would otherwise be thought of as Republicanleaning due to socioeconomic status, to identify more with the Democratic Party. Drawing on previous scholarship on social exclusion and Asian Americans, particularly from Kuo, Malhotra, and Mo (2017), we extend this work to the coronavirus crisis and Asian American partisan attitudes. Trump's anti-Asian remarks surrounding the coronavirus shape an environment characterized by social exclusion, where Asian Americans are targeted on the basis of racial group membership. This results in increased favorability toward the Democratic Party. Given the negative GOP racial rhetoric (elite emboldening) and increase in self-reported anti-Asian harassment (interpersonal social exclusion), Asian Americans may associate these incidents with the Republican Party, thus driving Asian Americans more toward the Democratic Party instead.

\section{Hypotheses}

We utilize two data sources in order to test our theoretical expectations. First, we use 1.4 million tweets related to COVID-19 over time as a measurement of anti-Asian societal level exclusion due to Trump's inflammatory comments. Next, we measure shifts in partisan attitudes over time using repeated cross-sectional weekly surveys, analyzing a total of 12,907 Asian Americans.

Using Twitter data in Study 1, we track the rise of antiAsian sentiment in the United States. We expect to see the following two patterns from this social media data:

H1A: Trump's rhetoric has popularized racially charged COVID19 terms such as the "Wuhan virus," "Chinese virus," and "Kung flu."

H1B: Anti-Asian attitudes have increased since the spread of COVID-19 in the United States. 
Using the survey data in Study 2, we investigate changes in partisan attitudes among Asian Americans. We expect to see the following two patterns in the survey data:

H2A (temporal change): Trump's anti-Asian and social exclusionary rhetoric has increased favorability toward the Democratic Party, the Democratic Party's presidential candidate at the time (Joe Biden), and partisan identification with the Democratic Party among Asian Americans.

H2в (cross-sectional variation): Trump's anti-Asian and social exclusionary rhetoric pushes Asian Americans most consistently to lean more Democratic relative to Whites, Latina/os, and African Americans.

\section{Study 1: Social Media Analysis}

\section{Data and Methods}

We identify the extent to which Trump made derogatory terms such as the "Chinese virus" popular and trace how anti-Asian attitudes have increased in the United States since the pandemic by analyzing more than one million COVID-19-related tweets. We expect that anti-Asian bias and attitudes are present in the United States among the general public but have increased during the spread of the coronavirus. We expect that Trump's usage of racially charged terms to be associated with an increase in the usage of the same terms in the digital public sphere.

Our first goal is to estimate changes in anti-Asian sentiment among the general public. The data source we utilize is the large-scale COVID-19 Twitter chatter dataset (v.15) created by Panacealab. ${ }^{11}$ These tweets were created between January and June 2020, and the number of those tweets composed in English was more than 59 million. We randomly selected $10 \%$ of these tweets, stratifying by months in which these tweets were created. We then identified tweets specifically created by Twitter users located in the United States. The number of tweets in the final dataset amounts to $1,394,468$. We also developed an $\mathrm{R}$ package which helps other researchers wrangle the large-scale Twitter data with little technical expertise on such data. ${ }^{12}$

Tracing keyword trends. COVID-19 has many names. COVID-19 and coronavirus are epidemiological terms used by the scientific community; other colloquial terms such as "Chinese virus," "Wuhan virus," and especially "Kung flu" are racially charged terms. The colloquial terms were popularized by the Trump administration and are negatively associated with Chinese/Asian communities. This contributes to social exclusion.

We first trace the trends of several racially charged terms and anti-racism-related terms, such as "Racist," "Racism," and "Anti-Asian" among COVID-19-related tweets created by users in the United States. We use both categories to differentiate those tweets targeting Asian Americans from other tweets opposing these anti-Asian attitudes.
We then replicate this analysis using Google search-trends data to strengthen external validity as Twitter users are not wholly representative of the U.S. population. This is because people do not create Twitter accounts randomly. Moreover, we are only analyzing a subset of Twitter users who tweeted about COVID-19. Therefore, it is important to demonstrate that the keyword trends, which we identified using the Twitter data, are not limited to that particular social media platform and dataset. For these reasons, we run the same data analysis using Google search API (Application Programming Interface). Although the Google search data is not collected via random sampling, Google search is more representative of the general population due to the accessibility of Google and its wider user base.

Tracing changes in topic model proportions. The Twitter and Google data analysis is effective at examining how Trump's speech popularized racially charged COVID-19 terms. However, if we take a look at the proportions of the tweets mentioning "Chinese virus," "Kung flu," and "Wuhan virus" (refer to figure A.1 in online appendix A), they were extremely marginal. Only $0.5 \%$ of the tweets mentioned these racially charges COVID-19 terms. In contrast, the proportions of the tweets that mentioned Asian, Chinese, or Wuhan were twenty times larger. Therefore, if we trace the rise of anti-Asian sentiment on social media exclusively focusing on these keyword trends, the conclusion we draw from the data analysis could be strongly biased.

However, analyzing the tweets related to Chinese or Wuhan is challenging because, in this case, what the keywords imply is not obvious. If someone tweeted "Chinese virus" or "Kung flu," the political and racial context is relatively clear. However, if someone tweeted about "COVID-19" and "China," it could be about the country, the virus, anti-Asian sentiment, or something else. In other words, many latent themes exist within these tweets. We needed a way to distinguish these themes to make an inference about these tweets. In order to go beyond keywords and try to analyze deeper textual contexts, we employ a machine-learning technique known as topic modeling. We assume that these themes (or topics) are clusters of tweets, and we can identify these topics based on how words in different tweets co-occur. Using the "stm" package in R (Roberts et al. 2014), we find that, in this case, three topics would be optimal given the tradeoff between exclusivity and semantic coherence (refer to figure A.2 in online appendix A). Topic modeling does not give us any specific meaning behind what the estimated topics are about. In order to learn what these topics are about substantively, researchers might read some samples of these topics and make subjective decisions. This aspect of topic modeling is time-consuming and could lead to post-hoc theorizing. To avoid this problem, we used a topic modeling method called keyword assisted topic 
models (keyATM) that was recently developed by Eshima, Imai, and Sasaki (2020). This helps us leverage a small number of keywords to generate a better classification schema that makes for easier interpretation. KeyATM is especially applicable to tweets, as Twitter hashtags are literally keywords. We extracted hashtags of the tweets that mentioned COVID-19 and either "Asian," "Chinese," or "Wuhan," and visualized them using a word cloud in figure $1 .{ }^{13}$ Based on the hashtags, we created two lists of words: anti-Asian (sentiment) and anti-racism. ${ }^{14}$ Figure A.4 in online appendix A shows the relative frequency of these keywords in the corpus by topic. Using these lists, we run keyword topic modeling and estimated topic proportions in the Twitter data and also traced how these proportions changed over time (dynamic topic modeling). ${ }^{15}$

\section{Results}

Keyword analysis. Our keyword analysis shows that Trump's rhetoric popularized racially charged COVID19 terms. The top panel in figure 2 shows the trends of

Figure 1

Hashtags of tweets mentioning "COVID-19" and either "Asian," "Chinese," or "Wuhan"

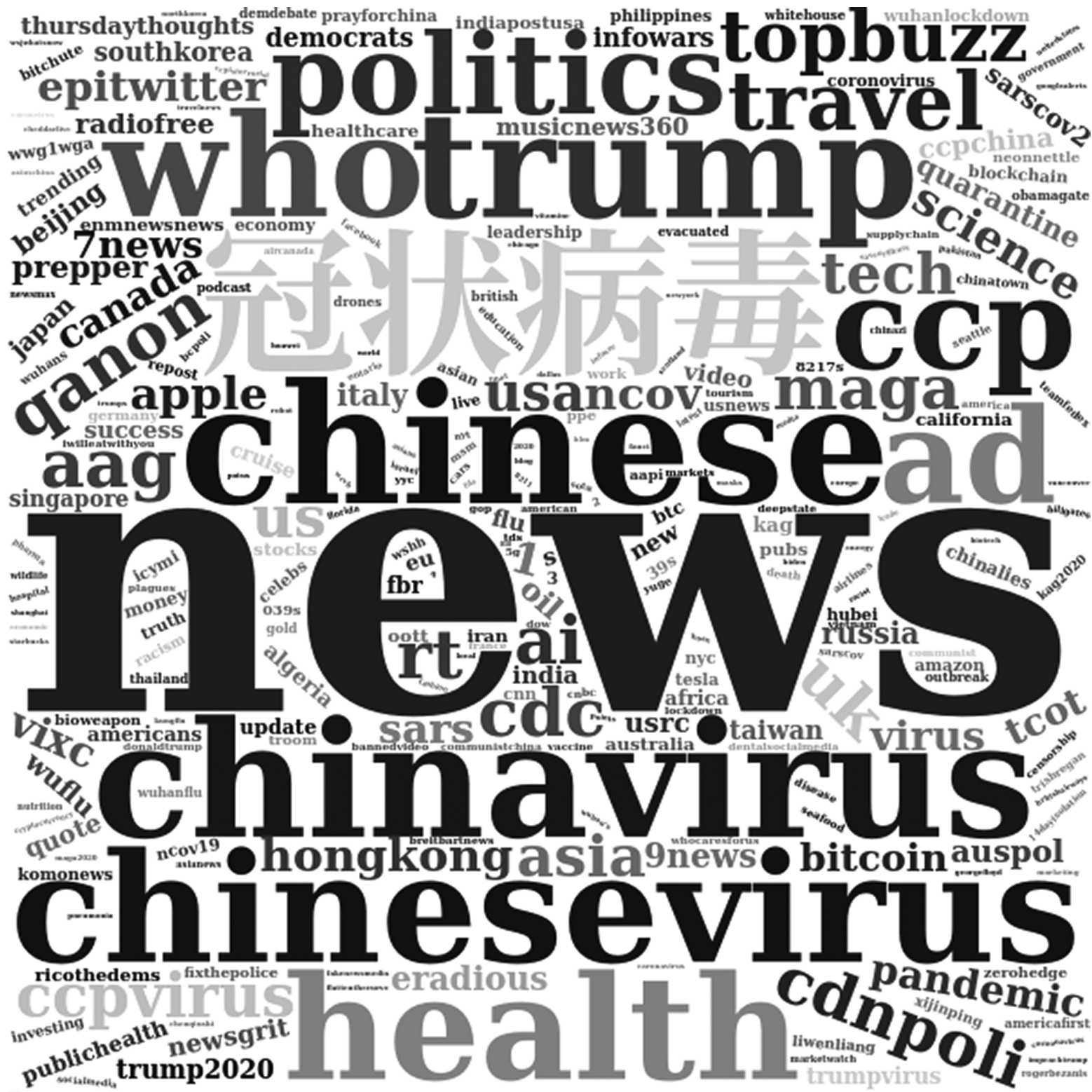




\section{Figure 2}

\section{Comparison between Google search and Twitter trends}

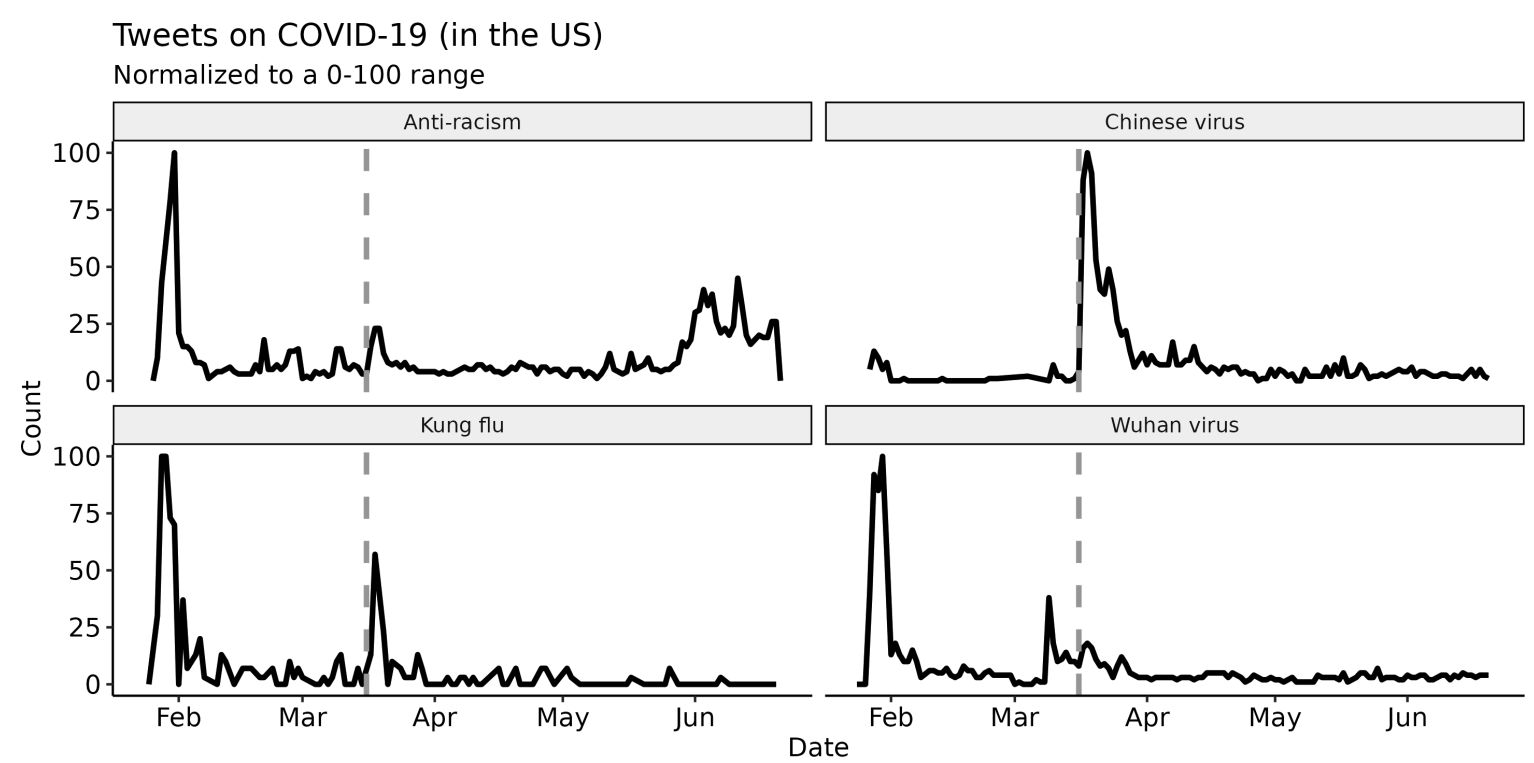

Google Searches on COVID-19 (In the US)

Normalized to a 0-100 range

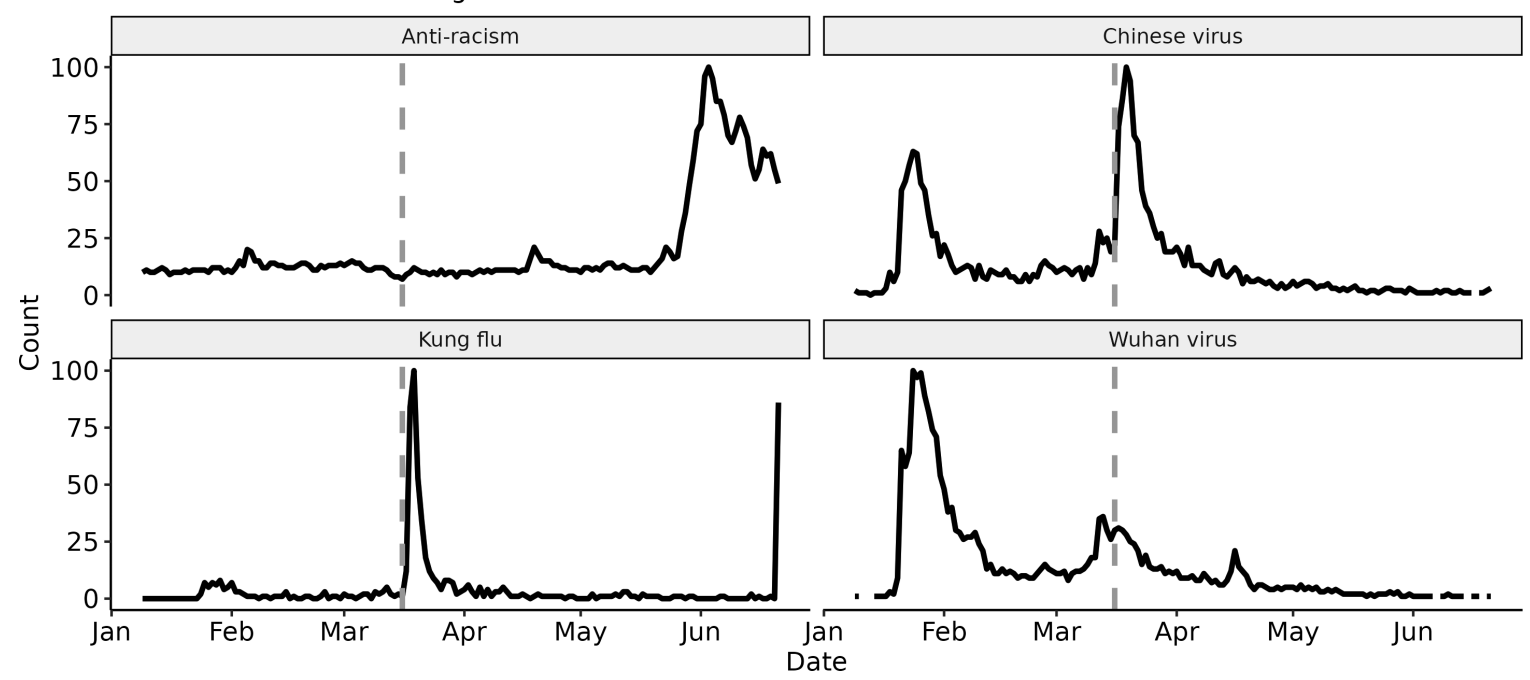

racially charged COVID-19 and anti-racism-related terms among the COVID-19-related tweets created by users in the United States. The X-axis indicates when these tweets were created and the $\mathrm{Y}$-axis represents the count of these tweets normalized to a $0-100$ range. The dark gray dashed line indicates when President Trump first referred to COVID-19 as the "Chinese virus." We find that "Wuhan virus," "Kung flu," and "anti-racism" were already popular terms among Twitter users in February 2020. This evidence shows that anti-Asian sentiment was present even before Trump made his anti-Asian rhetoric in March. However, Trump's role in strengthening anti-Asian rhetoric was also apparent. These terms' popularity on Twitter and Google search was fading until Trump used them in public speeches. Moreover, Trump's remarks made another derogatory term "Chinese virus" trend on Twitter, although their increasing rates varied to some extent. Whereas the number of tweets on "Kung flu," and "Wuhan virus" resurged relatively modestly, the tweets on "Chinese virus" increased exponentially.

In the bottom panel in figure 2, we also analyzed the Google search trends using a similar method to strengthen external validity. The bottom panel of figure 2 demonstrates that Twitter and Google trends are in parallel to a 
large extent. "Chinese flu" and "Wuhan virus" trended in January and February 2020. Nevertheless, their popularity soon decreased substantially. After Trump referred to COVID-19 as the "Chinese virus," Google users paid more substantive attention to "Chinese flu" as well as "Kung flu" and, to a lesser degree, "Wuhan virus." The results alleviate concerns about external validity.

Topic Modeling Analysis. Next, we turn to topic modeling. Here, the data are limited to the tweets that mentioned COVID-19 and either "Asian," "Chinese," or "Wuhan." Anti-Asian is a topic that represents tweets mentioning something negative about Asians. Anti-racism is a topic that represents tweets that oppose such anti-Asian attitudes.

The base topic modeling result (figure A.3 in online appendix A) shows that the proportions of anti-Asian and anti-racism topics are slightly above $30 \%$ in the corpus and close to each other (34\% and 33\%, respectively). The dynamic topic modeling in figure 3 shows that the proportions of both anti-Asian and anti-racism topics in the corpus surged in January when COVID-19 began to spread in the United States. This pattern is consistent with figure 2. The Twitter and Google data show that some anti-Asian terms were already popular in January and February. These anti-Asian terms were present even before Trump first framed the coronavirus as the "Chinese virus" in March. After Trump's initial comment, though, these anti-Asian terms spiked again in popularity.

Further, how Trump normalized this rhetoric is critical. Figure 2 shows that anti-Asian keywords were losing popularity on the Twitter platform until Trump revitalized references to the "Chinese virus." Trump racialized COVID-19 by referring to it as the Chinese virus, and he did so repeatedly and consistently. While Trump did not initiate anti-Asian sentiment, he helped to sustain it.
In addition, Trump's framing of COVID-19 as the Chinese virus matters because it creates a more explicit connection between the virus and a particular racial/ethnic group (Tversky and Kahneman 1981; Gilens 1999; Lakoff 2014). As other GOP elites also began to follow suit, this shaped an environment characterized by social exclusion within the mass public, especially for the targeted groupAsian Americans. Specifically, political elites' normalization of anti-Asian attitudes is problematic because many researchers have found a linkage between anti-Asian attitudes and hate crimes, especially during the COVID-19 pandemic (Lu and Sheng 2020). Trump, a prominent political elite, signaled to the mass public that such terms are acceptable and that anti-Asian bias was therefore justified. As more GOP elites and masses evoked and reinforced the racialized frame by either adopting or criticizing the racially charged COVID-19 terms, anti-Asian rhetoric became normalized and accepted as part of the everyday conversation regarding the pandemic. Our next goal is to assess how this elite-driven social exclusion in the masses shapes the partisan attitudes of Asian Americans.

\section{Study 2: Survey Data Analysis}

To measure partisan changes over time among Asian Americans, we use repeated cross-sectional surveys from Nationscape conducted by Democracy Fund and Principal Investigators at UCLA (Tausanovitch and Vavreck 2020). ${ }^{16}$ Nationscape is a weekly online survey of approximately 6,250 respondents, inclusive of Latina/os, Whites, African Americans, and Asian Americans. We leverage survey data on partisan attitudes between July 2019May 2020, before and after Trump begins to frame COVID-19 as the "Chinese virus." We analyze how his rhetoric has shaped individuals' partisan attitudes across

\section{Figure 3}

\section{Dynamic topic modeling analysis results}

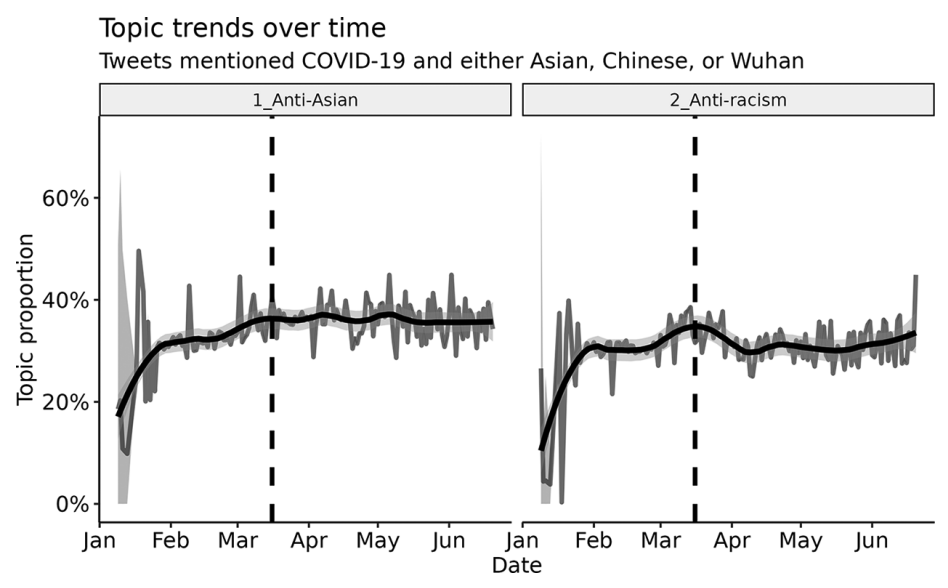


race through May 7, 2020 (access to survey data ended on this date at the time of writing this article). We examine a total of $n=284,078$ surveys across racial groups: Asian Americans $(n=12,907)$; African Americans $(n=32,464)$; Latina/os $(n=38,549)$; and Whites $(n=200,158)$. Purposive sampling, selecting respondents based upon their characteristics, is used to obtain a sample that is constructed to be representative of the population. As with Reny (2020), survey weights have been applied to accurately represent the population of interest. ${ }^{17}$ This data has been weighted by gender, census region, race, education, age, household language, and country of birth, comparing responses to the 2018 American Community Survey. ${ }^{18}$

We expect that Trump's anti-Asian rhetoric and further social exclusion has contributed to an increase in Asian Americans' favorability toward the Democratic Party, the Democratic Party's presidential nominee at the time (Joe Biden), ${ }^{19}$ as well as an increase in Democratic Party identification. First, we look at the data over time to see how Asian Americans have shifted in their partisan opinions. We then compare favorability toward the Democratic Party, its presidential candidate, and party identification before and after March 16, 2020, the date when Trump began to frame the coronavirus as the "Chinese virus." ${ }^{20}$ Finally, we compare these shifts in Asian American partisan attitudes to those of Latina/os, Blacks, and Whites.

We then conduct a pooled cross-sectional analysis of weekly surveys across each racial group to analyze how social exclusion uniquely influences the partisan attitudes of Asian Americans, relative to African Americans, Latina/ os, and Whites. ${ }^{21}$ We run regression models where our main independent variable of interest is an indicator for whether respondents completed their survey prior to March 16, 2020, before Trump's framing of COVID19 as the "Chinese virus" (0), or after March 16, 2020, following this frame (1). In regression models, we see how this indicator variable, called "Chinese virus," is associated with changes in Democratic-leaning attitudes controlling for gender, income, education, age, place of birth, religious affiliation, and ideology, specifications similar to that of Kuo, Malhotra, and Mo (2017). All control variables are scaled between $0-1.22$

In our pooled analyses of cross-sectional surveys, we include weekly fixed effects in our models. The subjects participating in each wave of the Nationscape data are different individuals; therefore, it is not plausible to apply an identical estimation model to each wave. Including weekly fixed effects reduces the subjects' variation between the waves because it allows the intercept to have a different value in each wave. Specifically, the "Chinese virus" variable's coefficient indicates the extent to which the variation in our dependent variables are associated with the main independent variable, controlling for differences in weeks. Our model specification is thus:

$$
\begin{aligned}
Y_{i, t}= & \beta_{0}+\beta_{1} \text { Trump Statementon Chinese Virus }_{t} \\
& +\beta_{2} \text { Female }_{i}+\beta_{3} \text { Income }_{i}+\beta_{4} \text { Education }_{i} \\
& +\beta_{5} \text { Age }_{i}+\beta_{6} \text { Placeof Birth }_{i}+\beta_{7} \text { Protestant }_{i} \\
& +\beta_{8} \text { Liberal }_{i}+\sigma_{t} \text { Week }_{t}+\varepsilon
\end{aligned}
$$

Here $i$ indicates an individual participant, and $t$ indicates a different wave; $i$ ranges from 1 to 6,730 and $t$ ranges from 1 to 42 .

We test the relationship between our main independent variable on four dependent variables. The first outcome variable is partisan identification: Democrat (1); Republican, Independent, or Something Else (0). We also assessed respondents' favorability of the Democratic Party and their favorability toward the Democratic Party's nominee Joe Biden in the 2020 presidential election. The favorability variables range from Very favorable, Somewhat favorable, Somewhat unfavorable, or Very unfavorable, and are recoded between 0 and 1, with the highest value indicating the most favorability. We also created a Democratic Party Index as a fourth dependent variable, which gives us a broad overview of partisan leanings using the three aforementioned questions. The scale sums the three measures together and divides them by three to range from 0 to 1 . Given the binary nature of the partisan identification variable, we ran logit regressions. For all other dependent variables, we ran OLS regressions.

\section{Results}

Descriptive analysis. Figure 4 displays how each racial group has changed in terms of Democratic-related attitudes on three measures. The bottom left panel in figure 4 shows that from right before Trump framed the coronavirus as the "Chinese virus" to after, Asian American identification with the Democratic Party increased by 6 points. There was some immediate drop off. However, about a month later, there was still a two-point increase compared to right before this framing. The group's favorability of the Democratic Party also increased from $57.6 \%$ to $61.6 \%$. Asian Americans' favorability toward Joe Biden substantially picked up by seven points as well. This is while Whites, Latina/os, and African Americans experienced much less of a change in these attitudes over time comparing pre-and post-Chinese virus statements. These estimates are especially important in light of the history of Asian American non-partisanship, where many consider themselves to be non-partisan, moderate, or Independent. ${ }^{23}$ The sustained change in party identification ( 2 points) is substantive due to how Asian Americans typically eschew party labels (Wong et al. 2011) and that Asian Americans are a rapidly growing proportion of the U.S. electorate (Budiman 2020).

Regression analysis. Next, we move to regression models, which will help account for some noise in the repeated 


\section{Figure 4}

\section{Democratic Party attitudes over time by racial/ethnic group}

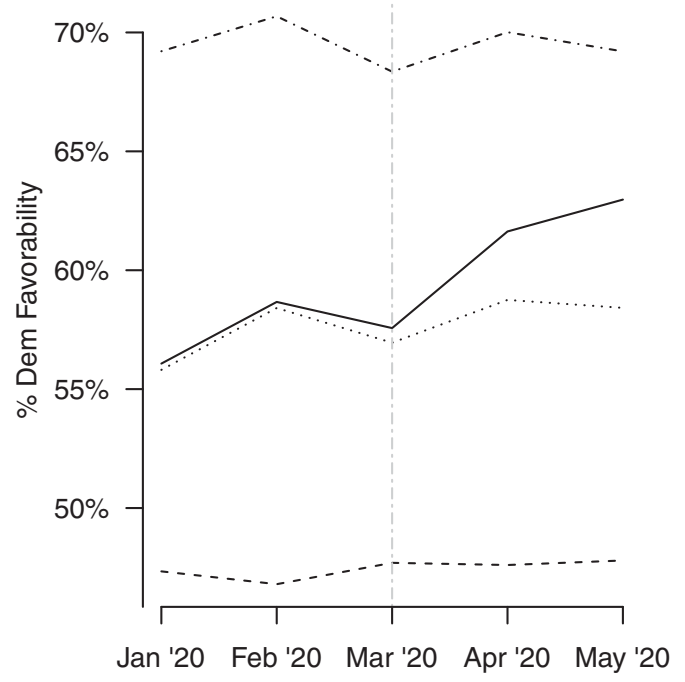

Date

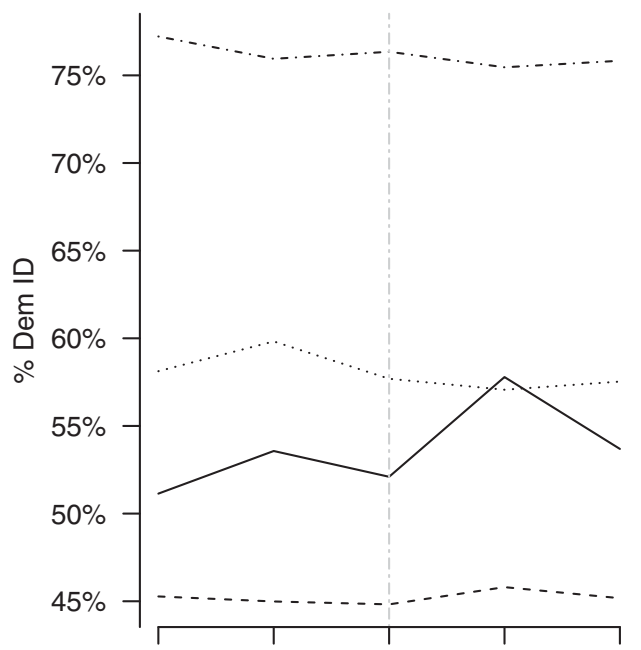

Jan '20 Feb '20 Mar'20 Apr '20 May '20

Date

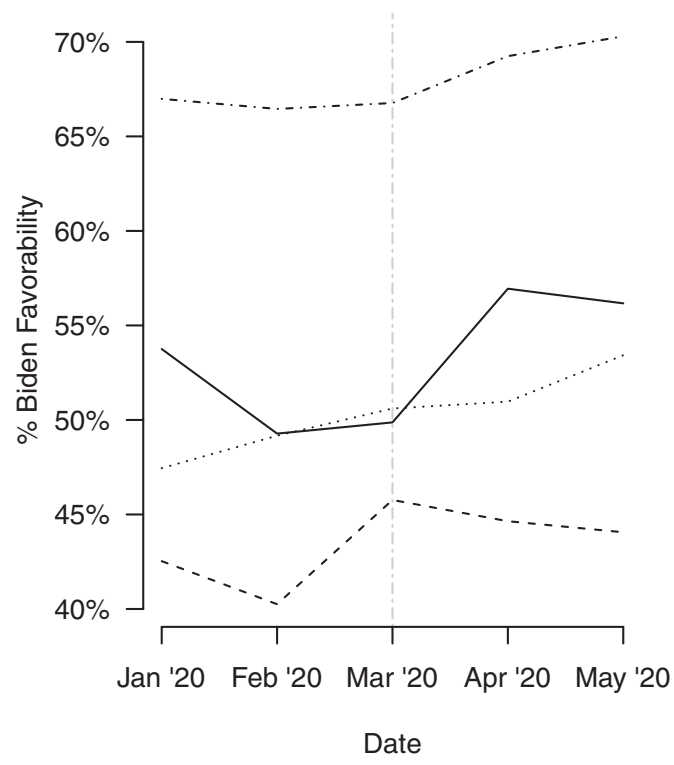

- - White

Latina/o

... Black

- Asian cross-sectional data. In doing so, we pool together all the data made available to us between July 2019-May 2020 and analyze separately by each racial group. As mentioned, our main independent variable of interest is an indicator for pre- or post-Chinese virus framing. In our models, we control for income, education, age, gender, place of birth, religious affiliation, and ideology. We also account for weekly fixed effects. For simplicity, we reported the change in predicted probabilities in leaning toward the Democratic Party comparing those measured post-Chinese virus to those surveyed pre-Chinese virus, controlling for confounders. Full output from regression models is available in online appendix B.

Figure 5 displays the change in predicted probability of Asian Americans' partisan attitudes comparing postChinese virus versus pre-Chinese virus, accounting for control variables and weekly fixed effects. The results suggest that Asian Americans' partisan attitudes lean more Democratic after Trump framed COVID-19 as the "Chinese virus." Democratic Party favorability increased by approximately six points; feelings toward the presumptive presidential nominee for the Democratic Party at the 


\section{Figure 5 \\ Change in Democratic-leaning attitudes after Trump's statement on the "Chinese virus" (Asian Americans only)}

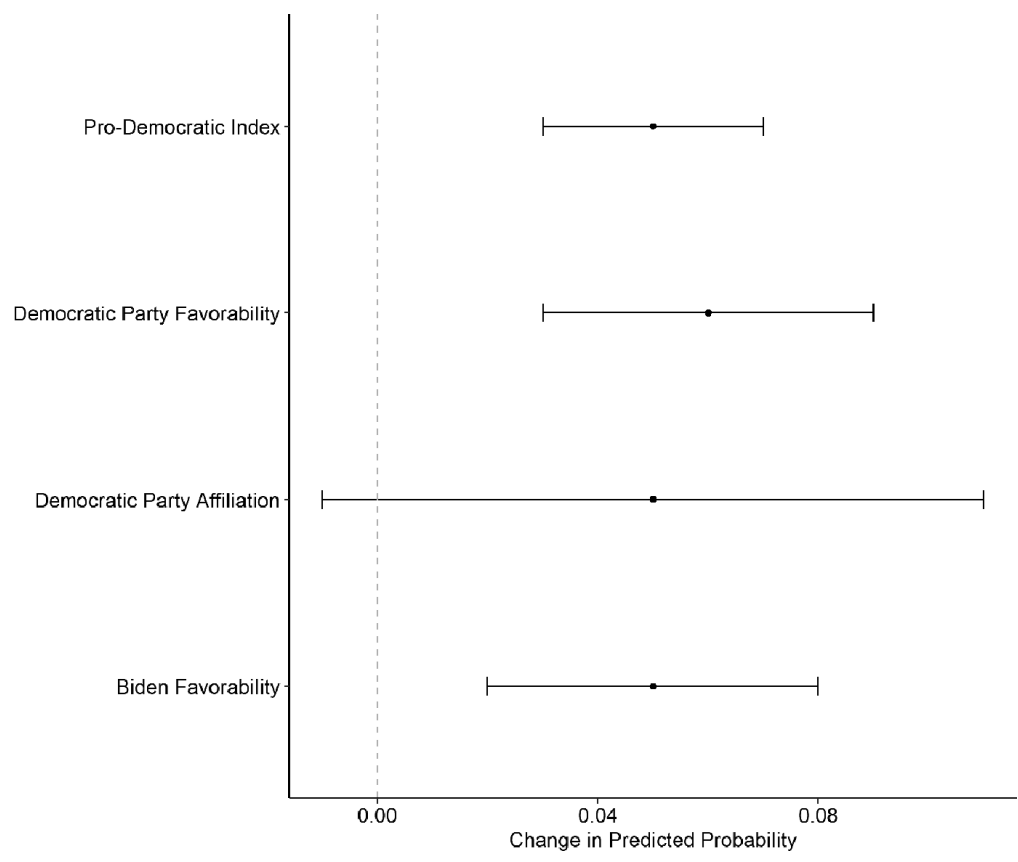

time also improved by an estimated 5 percentage points. Our results also show that Asian Americans' identification with the Democratic Party increased by about five percentage points after Trump's rhetoric (although $\mathrm{p}=0.156)$.

In testing our expectations further, in Hypothesis 2B, we want to test if this trend toward leaning more towards the Democratic party is unique to Asian Americans relative to other racial/ethnic groups. In doing so, we examine the extent to which Latina/os, African Americans, and Whites have changed as well. Figure 6 displays the result of this comparison, which also shows the predicted change in probability of partisan attitudes comparing post- and preChinese virus framing, controlling for other covariates in our models and accounting for weekly fixed effects (refer to online appendix B). Blacks also picked up in their favorability of Joe Biden but by an estimated percentage point lower than Asian American respondents. Before and after March 2020, Latina/o identification with the Democratic Party dropped. Biden favorability also dropped a bit after March 2020 among Whites. All other partisan attitudes have remained fairly unmoved before and after Trump framed COVID-19 as the "Chinese virus" for Latina/os, African Americans, and Whites.

For robustness, we estimated interaction models to better determine whether our "Chinese virus" variable indeed relates to Democratic partisan attitudes more substantively for Asian Americans compared to Latina/ os, Blacks, and Whites. Table 1 displays the results from our interaction models for the Democratic Party Index dependent variable. Full output from these regressions with all controls and fixed effects are available in online appendix B. We find that relative to Latina/os, Blacks, and Whites, Asian Americans are more likely to have significantly shifted toward holding more favorable attitudes toward the Democratic Party after Trump began framing COVID-19 as the Chinese virus by about two points more compared to all other non-Asian racial/ethnic groups.

The results from our analyses across racial/ethnic groups speaks to the uniqueness and consistency of how elitedriven social exclusion relates to more Democratic-leaning public opinion, specifically for Asian Americans. Trump's framing of the virus in racialized terms is disproportionately associated with leaning more Democratic for Asian Americans.

\section{Discussion and Conclusion}

The exclusionary environment during COVID-19, fueled by elite sources, has led Asian Americans to increase favorability with the Democratic Party. We demonstrate this with two studies. Study 1, based on an analysis of 1.4 million tweets over time, shows that Trump's usage of the term "Chinese virus" led to increased usage of "Chinese virus," "Kung flu," and other racialized terms in the masses. 


\section{Figure 6}

\section{Change in Democratic-leaning attitudes after Trump's statement on the "Chinese virus" across race/ethnicity}

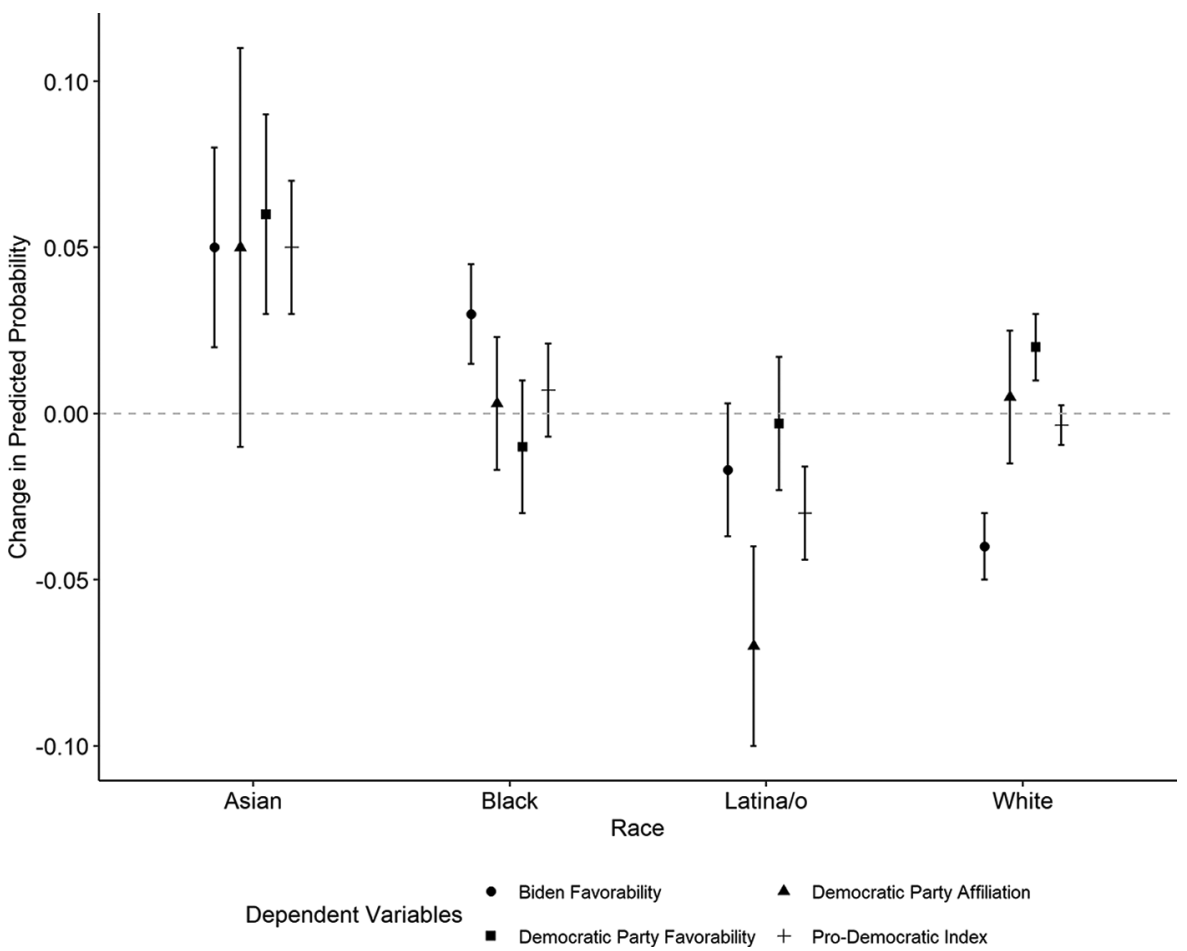

Table 1

Chinese virus and Democratic Party Index for Asian Americans relative to other racial/ethnic Groups

Dependent variable: Democratic Party Index

\begin{tabular}{|c|c|c|c|}
\hline & Asian + Black & Asian + White & Asian + Latina/o \\
\hline Trump Statement on "Chinese Virus" & $\begin{array}{c}0.016 \\
(0.013)\end{array}$ & $\begin{array}{l}-0.0005 \\
(0.006)\end{array}$ & $\begin{array}{l}-0.012 \\
(0.012)\end{array}$ \\
\hline $\begin{array}{l}\text { Trump Statement on "Chinese } \\
\text { Virus" * Asian }\end{array}$ & $0.017^{* \star}$ & $0.015^{\star \star}$ & $0.017^{* *}$ \\
\hline & $(0.008)$ & $(0.006)$ & $(0.008)$ \\
\hline Constant & $\begin{array}{l}0.461^{* * *} \\
(0.010)\end{array}$ & $\begin{array}{l}0.308^{* * *} \\
(0.005)\end{array}$ & $\begin{array}{l}0.449^{\star \star *} \\
(0.010)\end{array}$ \\
\hline Weekly Fixed Effects & Yes & Yes & Yes \\
\hline Observations & 41,756 & 199,065 & 45,858 \\
\hline $\mathrm{R}^{2}$ & 0.163 & 0.243 & 0.110 \\
\hline Adjusted $\mathrm{R}^{2}$ & 0.162 & 0.243 & 0.109 \\
\hline Residual Std. Error & $0.292(\mathrm{df}=41705)$ & $0.288(\mathrm{df}=199014)$ & $0.318(\mathrm{df}=45807)$ \\
\hline F Statistic & $\begin{array}{c}161.929^{\star \star \star}(\mathrm{df}=50 \\
41705)\end{array}$ & $\begin{array}{c}1,276.554^{\star \star \star}(\mathrm{df}=50 \\
199014)\end{array}$ & $\begin{array}{c}113.662^{* \star \star}(\mathrm{df}=50 \\
45807)\end{array}$ \\
\hline
\end{tabular}

Note: OLS regression coefficients with standard errors in parentheses. ${ }^{* \star \star} p<0.01,{ }^{* \star} p<0.05,{ }^{*} p<0.01$. 
We also find that anti-Asian sentiment has risen since the outbreak of COVID-19 in the United States. This more explicit racialized association between the pandemic and Asian Americans led by Trump and other GOP elites evokes, reinforces, and justifies hate against Asian Americans. Study 2 leverages pooled data from weekly crosssectional surveys. We demonstrate that Asian Americans have leaned more toward the Democratic Party on various partisan measures after Trump's usage of the Chinese virus. By comparison, the partisan attitudes of Whites, Latina/os, and African Americans do not change as much or as consistently during the same time period. Taken together, we find support for our hypotheses that elite messaging regarding the coronavirus has contributed and amplified social exclusion for Asian Americans and is turning this group uniquely away from the Republican Party. ${ }^{24}$

Due to the diversity of the Asian American community, we also conducted disaggregated analysis by national origin. Our results suggest that this change in partisanship is strongest for Chinese Americans; non-Chinese groups such as Indian and Korean Americans also trend more towards the Democratic Party, but the difference is not statistically significant on conventional standards. Traditionally Republican-leaning groups such as Filipina/o and Vietnamese Americans were less likely to be swayed towards the Democratic Party than Chinese Americans. Given the historical differences in baseline partisan attitudes within the Asian American community before the pandemic (Lien 1994; Lien, Conway, and Wong 2003; Wong et al. 2011), as well as a loss in power with disaggregated sample sizes, we cannot make strong conclusions regarding national-origin differences (refer to online appendix B). ${ }^{25}$

Our project adds to existing work on elite messaging and social exclusion (Kuo, Malhotra, and Mo 2017) by demonstrating how elite-driven rhetoric contributes to the activation of latent anti-Asian bias, leading to normalization of social exclusion at the mass public level. We also find evidence of the "Trump effect" (Newman et al. 2019) wherein Trump's prejudiced speech activates and removes constraints upon already biased individuals, leading them to be more willing to express their prejudice. We also add to the literature on elite driven theories of public opinion, race, and ethnic politics, and marginalized groups' politics during times of pandemic (see Adida, Dionne, and Platas 2020; Cohen 1999; Darling-Hammond et al. 2020; Dionne and Turkmen 2020; Gadarian, Goodman, and Pepinsky 2021; Hoppe 2018; Nelkin and Sander 2020; Reny and Barreto 2020).

We recognize the limitations of this project and offer avenues for future work. Due to accessibility, we only utilized data made available to us through May 2020, which cannot capture whether or not (or how) respondents actually voted in the 2020 presidential election. ${ }^{26}$ Also, given the difficulty in sampling Asian American voters such as language barriers and incidence rates, as well as wide variance in exit poll estimates, ${ }^{27}$ we are cautious about not making claims about how this factored into the actual breakdown of the 2020 presidential election. Future work may leverage precinct-level election returns released by county registrars (Sadhwani 2020, 2021; Lee, Chan, and Masuoka 2021; Leung 2021) to estimate the partisan preferences of Asian Americans at the local and state levels. Some preliminary studies on vote performance that leverage Asian Americans' voter database files do estimate that approximately $67 \%$ of Asian American voters voted for Biden (Ghitza and Robinson 2021). Their analysis further suggests that claims about Trump doing better among Asian American voters in 2020 compared to 2016 are likely overstated. Ghitza and Robinson (2021) find that Trump only did 1\% better among Asian Americans across the two election cycles. Their estimates of vote shifting among other minority groups, such as Blacks and Latina/os, find that they did lean heavier towards Trump in 2020, relative to Asian Americans $(+3 \%$ and $+8 \%$, respectively). We align with their argument, in addition, that because Asian Americans grew in their share of the electorate and the group's turnout increased 39\% from 2016 (62\% overall turnout in 2020), this largely "benefitted Democrats."

The murders of Daoyou Feng, Delaina Ashley Yaun Gonzalez, Hyun Jung Grant, Suncha Kim, Paul Andre Michels, Soon Chung Park, Xiaojie Tan, and Yong Ae Yue in Atlanta, Georgia, ${ }^{28}$ the rise in anti-Asian hate crimes (Jeung and Nham 2020), and the continued usage of the term "China virus" by former President Trump suggests that anti-Asian bias continues to perpetuate. ${ }^{29}$ The results of our project here have implications for future presidential elections as partisan attitudes are key indicators of propensity to vote. Asian Americans are the fastestgrowing racial group in the United States (Budiman and Ruiz 2021). As a growing community with an increasing number of eligible voters, Asian Americans are poised to take a more important position in the U.S. electorate, especially in swing states such as Nevada, Virginia, and Georgia. This is not just in federal elections but in state and local politics as well. The rapid population growth and continued social exclusion at the hands of elites and the public necessitates a greater study of this group moving forward.

\section{Supplementary Materials}

To view supplementary material for this article, please visit http://doi.org/10.1017/S1537592721003091.

Appendix A. Twitter Data

Appendix B. Survey Data

\section{Acknowledgements}

The authors are grateful for feedback and comments from discussants and participants of the 2020 American Political 
Science Association Annual Meeting, where a previous version of this paper was presented. We also thank Charles Crabtree and Michael Tesler for their generous support through various stages of this manuscript.

\section{Notes}

1 https://www.washingtonpost.com/graphics/2020/ world/coronavirus-2020-timeline/.

2 https://apps.who.int/iris/bitstream/ handle/10665/163636/WHO_HSE_FOS_15.1_ eng.pdf.

3 https://www.nbcnews.com/news/asian-america/cdcchief-spurns-term-chinese-coronavirus-used-goplawmakers-n1156656.

4 https://www.npr.org/2017/06/23/533977175/hislife-cut-short-vincent-chin-is-remembered-for-whatmight-have-been.

5 http://www.asianpacificpolicyandplanningcouncil. org/wp-content/uploads/Press_Release_4_23_20. pdf.

6 Having high socioeconomic status and identifying as Evangelical Christians are traits associated with White Republican preference. Studies in African American politics find that income is not related to partisan affiliation due to factors such as historical adversity and group consciousness taking precedence over individual factors such as income and educational attainment; Dawson 1994; White and Laird 2020; Philpot 2017. Latina/os, to a certain extent, view political parties through a policy-based lens rather than a socioeconomic one; Barreto and Woods 2005; Alvarez and Bedolla 2003.

7 Asian Americans also hold more progressive views compared to Whites on issues such as healthcare; Wong et al. 2011.

8 See also Chan 2020 who also discusses how discrimination against Asian Americans during COVID-19 may mobilize the group's online and offline political activism.

9 https://www.nbcnews.com/news/asian-america/sencornyn-china-blame-coronavirus-because-people-eatbatsn1163431; https://www.health.com/condition/ infectious-diseases/coronavirus-bat-soup.

10 Other cases of disease association with perceived foreigner groups include $\mathrm{H} 1 \mathrm{~N} 1$, which was associated with Mexican-Americans, and SARS with Chinese Americans.

11 The keywords used to search the tweets related to COVID-19 were "COVD19,"

"CoronavirusPandemic," "COVID 19," "2019nCoV," "CoronaOutbreak," "coronavirus," "WuhanVirus," "covid19," "coronaviruspandemic," "covid-19," "2019ncov," "coronaoutbreak,"

"wuhanvirus." For more information on the data collection, see http://www.panacealab.org/covid19/.
12 The package helps to turn the timestamp variable in the tweet Java Script Object Notation (JSON) file into a date variable and identifies whether the location indicated by Twitter users is in the United States or not. For more information, see https://github.com/ jaeyk/tidyethnicnews.

13 We also created an interactive version of the word cloud using a Shiny app: https://jaeyeonkim. shinyapps.io/covid19antiasian_hashcloud/. If you hover a cursor over a hashtag, you can find how many times that particular hashtag was mentioned in the corpus.

14 The hashtags related to anti-Asian sentiment are "wuhanvirus," "chinesevirus," "chinavirus," "wuhancoronavirus," "wuhanpneumonia," "ccpvirus," and "chinaliedpeopledied." The hashtags related to anti-racism are "antiasian," "racism," and "racist."

15 For the methodological foundation of dynamic topic modeling, see Blei and Lafferty 2006.

16 Ideally, we would have panel data to track partisan attitude changes among Asian Americans compared to other racial groups. To the best of the authors' knowledge, we are not aware of such data sources.

17 https://www.voterstudygroup.org/uploads/reports/ Data/NS-Methodology-RepresentativenessAssessment.pdf.

18 A full report on survey collection methodology is available: https://www.voterstudygroup.org/uploads/ reports/Data/Nationscape-User-Guide_2020feb24. pdf. We thank Michael Tesler for providing us initial access to this survey data.

19 The data for this project was collected and analyzed prior to Biden's confirmation as the Democratic nominee.

20 We determined this time point based on this timeline of events related to COVID-19: https://abcnews.go. $\mathrm{com} /$ Health/timeline-coronavirus-started/story?id= 69435165.

21 By no means are we saying that Asian Americans are a monolithic group; however the average non-Asian American in the United States tends to regard all Asians as being similar or the same; Le Espiritu 1992; Lee and Ramakrishnan 2020.

22 Replication files are available at https://doi. org/10.7910/DVN/5DHYTU.

23 AAPI Data estimates that about $40 \%$ of Asian Americans identify as Independent: https://aapidata. com/infographic-2018-partyid/.

24 Alternative arguments might suggest that it is not Trump's rhetoric nor social exclusion, but the economic effects of COVID-19 that affects Asian Americans' partisan attitudes. We rule out this possibility in two ways. Asian Americans are a minoritized community but a pan-ethnic group that has a 
socioeconomic level that is higher than average. The survey data we use is reflective of this. Having recoded household income level from 0 (lowest) to 1 (highest), Asian Americans have a higher average household income than Whites, Blacks, and Latina/os in our data. Additionally, we looked to see how Asian Americans of high income and low income politically responded after Trump framed COVID-19 as the "Chinese virus." We find no significant difference in how high- and low-income Asian Americans shifted in terms of their lean toward the Democratic Party (refer to online appendix B). Asian Americans uniquely shift more towards holding democratic-related attitudes as a result of Trump's framing of COVID-19 in racialized and exclusionary terms.

25 We note that Japanese Americans' results are puzzling and especially urge future research to look more into how social exclusion shapes partisan attitudes among them and across all other individual national-origin groups.

26 Since we were only able to analyze survey data through May 2020, we also cannot measure the change in actual vote choice for Biden relative to Trump, which took place in November 2020.

27 https://www.npr.org/2017/04/18/524371847/ trump-lost-more-of-the-asian-american-vote-thanthe-national-exit-polls-showed.

28 https://www.theguardian.com/us-news/2021/ mar/19/atlanta-spa-shootings-victims-named.

29 https://www.newsweek.com/donald-trump-saidchina-virus-just-before-atlanta-shootings-1576756.

\section{References}

Adida, Claire, Kim Yi Dionne, and Melina Platas. 2020. "Ebola, Elections, and Immigration: How Politicizing an Epidemic Can Shape Public Attitudes." Politics, Groups, and Identities 8(3): 488-514.

Alvarez, R. Michael, and Lisa García Bedolla. 2003. "The Foundations of Latino Voter Partisanship: Evidence from the 2000 Election." Journal of Politics 65(1) : $31-49$.

Arora, Maneesh, and Hannah Kim. 2020. Stopping the Hate: Political Condemnations of Anti-Asian Rhetoric during the COVID-19 Crisis." Journal of Asian American Studies 23(3): 387-405.

Barreto, Matt, and Nathan Woods. 2005. "The AntiLatino Political Context and Its Impact on GOP Detachment and Increasing Latino Voter Turnout in Los Angeles County." In Diversity in Democracy: Minority Representation in the United States, ed. Gary Segura and Shawn Bowler, 148-169. Charlottesville: University of Virginia Press.

Blei, David M., and John D. Lafferty. 2006. "Dynamic Topic Models." Proceedings of the 23rd International
Conference on Machine Learning, Pittsburgh, PA, June 25-29.

Broockman, David E., and Daniel M. Butler. 2017. “The Causal Effects of Elite Position-Taking on Voter Attitudes: Field Experiments with Elite Communication." American Journal of Political Science 61(1): 208-21.

Budiman, Abby. 2020. "Asian Americans Are the FastestGrowing Racial or Ethnic Group in the US Electorate.” Pew Research Center. (https://pewrsr.ch/2WBvxf6).

Budiman, Abby, and Neil G. Ruiz. 2021. "Key Facts about Asian Americans, a Diverse and Growing Population.” Pew Research Center. (https:// pewrsr.ch/3e3t4nF).

Campbell, Angus, Philip E. Converse, Warren E. Miller, and Donald E. Stokes. 1960. The American Voter. Hoboken, NJ: Wiley.

Campbell, Angus, Philip E. Converse, Warren E. Miller, and Donald E. Stokes. 1966. Elections and the Political Order. Hoboken, NJ: Wiley.

Carmines, Edward G., and James A. Stimson. 1989. Issue Evolution: Race and the Transformation of American Politics. Princeton, NJ: Princeton University Press.

Chan, Nathan. 2020. "Political Inequality in the Digital World: The Puzzle of Asian American Political Participation Online." Political Research Quarterly. (https://doi.org/10.1177\%2F1065912920945391).

Cheryan, Sapna, and Benoît Monin. 2005. "'Where Are You Really From?' Asian Americans and Identity Denial." Journal of Personality and Social Psychology 89(5): 717-30.

Cohen, Cathy. 1999. The Boundaries of Blackness: AIDS and the Breakdown of Black Politics. Chicago: University of Chicago Press.

Costello, Maureen B. 2016. "The Trump Effect: The Impact of the Presidential Campaign on Our Nation's Schools." Southern Poverty Law Center, April 13. (https://www.splcenter.org/20160413/trump-effectimpact-presidential-campaign-our-nations-schools).

Darling-Hammond, Sean, Eli Michaels, Amani Allen, David Chae, Marilyn Thomas, Thu Nguyen, Mahasin Mujahid, and Rucker Johnson. 2020. "After 'The China Virus' Went Viral: Racially Charged Coronavirus Coverage and Trends in Bias Against Asian Americans." Health Education Behavior 47(6): 870-79.

Dawson, Michael C. 1994. Behind the mule: Race and Class in African-American Politics. Princeton, NJ: Princeton University Press.

Dionne, Kim Yi, and Fulya Turkmen. 2020. "The Politics of Pandemic Othering: Putting COVID-19 in Global and Historical Context." International Organization 74(1): 213-30.

Druckman, James N. 2001. "On the Limits of Framing Effects: Who Can Frame?" Journal of Politics 63(4): 1041-66. 
Eshima, Shusei, Kosuke Imai, and Tomoya Sasaki. 2020. "Keyword Assisted Topic Models." arXiv preprint arXiv:2004.05964.

Fiske, Susan Tufts. 2018. "Stereotype Content: Warmth and Competence Endure." Current Directions in Psychological Science 27(2): 67-73.

Fuchs, Chris. 2016. "Clinton Won the Asian-American Vote, but Some Swing States Turned Toward Trump: Exit Poll." NBC News, November 16. (https:// www.nbcnews.com/news/asian-america/clinton-wonasian-american-vote-some-swing-states-turned-towardn684716).

Gadarian, Shana, Sarah Goodman, and Tom Pepinsky. 2021. "Partisanship, Health Behavior, and Policy Attitudes in the Early Stages of the COVID-19 Pandemic." PLOS One 16(4): 1-13.

Gelman, Andrew. 2010. Red State, Blue State, Rich State, Poor State: Why Americans Vote the Way They DoExpanded Edition. Princeton, NJ: Princeton University Press.

Gelman, Andrew, Lane Kenworthy, and Yu-Sung Su. 2010. "Income Inequality and Partisan Voting in the United States." Social Science Quarterly 91(5): 1203-19.

Ghitza, Yair, and Jonathan Robinson. 2021. "What Happened in 2020." Catalist. (https://catalist.us/whnational/).

Gilens, Martin. 1999. Why Americans Hate Welfare: Race, Media, and the Politics of Antipoverty Policy. Chicago: University of Chicago Press.

Hajnal, Zoltan L., and Jeremy D. Horowitz. 2014. "Racial Winners and Losers in American Party Politics." Perspectives on Politics 12(1): 100-18.

Hajnal, Zoltan, and Taeku Lee. 2011. Why Americans Don't Join the Party: Race, Immigration, and the Failure (of Political Parties) to Engage the Electorate. Princeton, NJ: Princeton University Press.

Haynes, Chris, Jennifer L. Merolla, and S. Karthick Ramakrishnan. 2016. Framing Immigrants: News Coverage, Public Opinion, and Policy. New York: Russell Sage Foundation.

Hoppe, Trevor. 2018. “'Spanish Flu': When Infectious Disease Names Blur Origins and Stigmatize Those Infected." American Journal of Public Health 108(11): 1462-64.

Hua, Whiteney, and Jane Junn. 2021. “Amidst Pandemic and Racial Upheaval: Where Asian Americans Fit." Journal of Race, Ethnicity, and Politics 6(1): 16-32.

Jeung, R., and K. Nham. 2020. "Incidents of Coronavirus-Related Discrimination.” A Report for A3PCON and CAA, April 23. Los Angeles: Asian Pacific Policy and Planning Council.

Jeung, Russell, Aggie Yellow Horse, Tara Popovic, and Richard Lim. 2021. "Stop AAPI Hate National Report.” Stop AAPI Hate. (https://stopaapihate.org/wp-
content/uploads/2021/05/Stop-AAPI-Hate-ReportNational-210316.pdf).

Junn, Jane. 2007. "From Coolie to Model Minority: U.S. Immigration Policy and the Construction of Racial Identity." Du Bois Review: Social Science Research on Race 4(2): 355-73.

Kim, Claire Jean. 1999. "The Racial Triangulation of Asian Americans.” Politics \& Society 27(1): 105-38.

Kinder, Donald R. 2013. "Prejudice and Politics." The Oxford Handbook of Political Psychology. DOI: 10.1093/oxfordhb/9780199760107.001.0001

Kuo, Alexander, Neil Malhotra, and Cecilia Hyunjung Mo. 2017. "Social Exclusion and Political Identity: The Case of Asian American Partisanship." Journal of Politics 79(1): 17-32.

Lakoff, George. 2014. The All New Don't Think of an Elephant! Know Your Values and Frame the Debate. White River Junction, VT: Chelsea Green Publishing.

Le Espiritu, Yen. 1992. Asian American Panethnicity: Bridging Institutions and Identities. Philadelphia, PA: Temple University Press.

Lee, Jennifer, and Karthick Ramakrishnan. 2020. "Who Counts as Asian." Ethnic and Racial Studies 43(10): 1733-56.

Lee, Jessica, Nathan Kar Ming Chan, and Natalie Masuoka. 2021. "From Affirmative Action to Gig Economy: Racial Differences in the Support for California Propositions in the 2020 Election." UCLA Latino Policy \& Politics Initiative. (https:// latino.ucla.edu/wp-content/uploads/2021/08/LPPI_ CA-Proposition-2020-Report_02.18.pdf).

Lenz, Gabriel S. 2013. Follow the Leader? How Voters Respond to Politicians' Policies and Performance. Chicago: University of Chicago Press.

Leung, Vivien. 2021. "Asian American Candidate Preferences: Evidence from California." Political Behavior. (https://doi.org/10.1007/s11109-02009673-8).

Leung, Vivien, and Daeun Song. 2021. "New Directions in the Study of Asian American Politics, Part I: Affirmative Action." PS: Political Science and Politics 54(2): 240-43.

Lien, Pei-te. 1994. "Ethnicity and Political Participation: A Comparison between Asian and Mexican Americans." Political Behavior 16(2): 237-64.

Lien, Pei-te, M. Margaret Conway, and Janelle Wong. 2003. "The Contours and Sources of Ethnic Identity Choices among Asian Americans.” Social Science Quarterly 84(2): 461-81.

Liu, Marian. 2020. "The Coronavirus and the Long History of Using Diseases to Justify Xenophobia." The Washington Post. (https://www.washingtonpost.com/ nation/2020/02/14/coronavirus-long-history-blamingthe-other-public-health-crises/). 
Lu, Runjing, and Yanying Sheng. 2020. "From Fear to Hate: How the Covid-19 Pandemic Sparks Racial Animus in the United States." 21st-Century China Center Research Paper 2021-11. (https:// doi.org/10.2139/ssrn.3646880).

Margolin, Josh. 2020. "FBI Warns of Potential Surge in Hate Crimes against Asian Americans amid Coronavirus." ABC News, March 27. (https:// abcnews.go.com/US/fbi-warns-potential-surge-hatecrimes-asian-americans/story?id=69831920).

McClain, Paula D., Jessica D. Johnson Carew, Jr., Eugene Walton, and Candis S. Watts. 2009. "Group Membership, Group Identity, and Group Consciousness: Measures of Racial Identity in American Politics?" Annual Review of Political Science 12(1): 471-85.

Mendelberg, Tali. 2001. The Race Card: Campaign Strategy, Implicit Messages, and the Norm of Equality. Princeton, NJ: Princeton University Press.

Müller, Karsten, and Carlo Schwarz. 2020. "From Hashtag to Hate Crime: Twitter and Anti-Minority Sentiment." (https://doi.org/10.2139/ssrn.3149103).

Nelkin, Dorothy, and Gilman Sander. 2020. "Placing Blame for Devastating Disease.” Social Research 55(3): 361-78.

Newman, Benjamin, Jennifer L. Merolla, Sono Shah, Danielle Casarez Lemi, Loren Collingwood, and S. Karthick Ramakrishnan. 2019. "The Trump Effect: An Experimental Investigation of the Emboldening Effect of Racially Inflammatory Elite Communication." British Journal of Political Science 51(3): 1138-59.

Nguyen, Jenny, J. Scott Carter, and Shannon K. Carter. 2019. "From Yellow Peril to Model Minority: Perceived Threat by Asian Americans in Employment." Social Science Quarterly 100(3): 565-77.

Oskooii, Kassra A. R. 2018. "Perceived Discrimination and Political Behavior." British Journal of Political Science 50(3): 867-92.

Philpot, Tasha S. 2017. Conservative but Not Republican: The Paradox of Party Identification and Ideology among African Americans. New York: Cambridge University Press.

Pérez, Efrén O. 2015. "Xenophobic Rhetoric and Its Political Effects on Immigrants and Their Co-Ethnics." American Journal of Political Science 59(3): 549-64.

Raychaudhuri, Tanika. 2018. "The Social Roots of Asian American Partisan Attitudes." Politics, Groups, and Identities 6(3): 389-410.

—. 2020. "Socializing Democrats: Examining Asian American Vote Choice with Evidence from a National Survey." Electoral Studies 63: 102114. (https:// doi.org/10.1016/j.electstud.2019.102114).

Reny, Tyler. 2020. "Masculine Norms and Infectious Disease: The Case of COVID-19." Politics \& Gender 18(4): 1028-35.
Reny, Tyler T., and Matt A. Barreto. 2020.

"Xenophobia in the Time of Pandemic: Othering, Anti-Asian Attitudes, and COVID-19." Politics, Groups, and Identities. (https://doi.org/10.1080/ 21565503.2020.1769693).

Roberts, Margaret E., Brandon M. Stewart, Dustin Tingley et al. 2014. "stm: R Package for Structural Topic Models." Journal of Statistical Software 10(2): $1-40$.

Rose, Max, and Frank R. Baumgartner. 2013. "Framing the Poor: Media Coverage and U.S. Poverty Policy, 1960-2008." Policy Studies Journal 41(1): 22-53. (https://onlinelibrary.wiley.com/doi/pdf/10.1111/ psj.12001).

Sadhwani, Sara. 2020. “Asian American Mobilization: The Effect of Candidates and Districts on Asian American Voting Behavior." Political Behavior. (https:// doi.org/10.1007/S11109-020-09612-7).

Sadhwani, Sara. 2021. "The Influence of Candidate Race and Ethnicity: The Case of Asian Americans." Politics, Groups, and Identities. (https:// doi.org/10.1080/21565503.2021.1877749).

Schneider, Saundra K., and William G. Jacoby. 2005. "Elite Discourse and American Public Opinion: The Case of Welfare Spending." Political Research Quarterly 58(3): 367-79.

Tausanovitch, Chris, and Lynn Vavreck. 2020. "Democracy Fund + UCLA Nationscape." (www.voterstudygroup.org.nationscape).

Tesler, Michael. 2012. "The Spillover of Racialization into Health Care: How President Obama Polarized Public Opinion by Racial Attitudes and Race." American Journal of Political Science 56(3): 690-704.

Tessler, Hannah, Meera Choi, and Grace Kao. 2020. "The Anxiety of Being Asian American: Hate Crimes and Negative Biases During the COVID-19

Pandemic." American Journal of Criminal Justice 45(4): 636-46.

Trauner, Joan B. 1978. "The Chinese as Medical Scapegoats in San Francisco, 1870-1905." California History 57(1): 70-87.

Tversky, Amos, and Daniel Kahneman. 1981. "The Framing of Decisions and the Psychology of Choice." Science 211(4481): 453-58.

Valentino, Nicholas A., Vincent L. Hutchings, and Ismail K. White. 2002. "Cues That Matter: How Political Ads Prime Racial Attitudes during Campaigns." American Political Science Review 96(1): 75-90.

White, Ismail K., and Chryl N. Laird. 2020. Steadfast Democrats: How Social Forces Shape Black Political Behavior. Princeton, NJ: Princeton University Press. Wong, Janelle S. 2021. "What the Media Gets Wrong About Anti-Asian Hate.” Medium, June 23. (https:// 
stopasianhate.medium.com/what-the-media-getswrong-about-anti-asian-hate-369656a98684).

Wong, Janelle S., S. Karthick Ramakrishnan, Taeku Lee, and Jane Junn. 2011. Asian American Political

Participation: Emerging Constituents and Their Political Identities. New York: Russell Sage Foundation.
Zaller, John. 1992. The Nature and Origins of Mass Opinion. New York: Cambridge University Press.

Zou, Linda X., and Sapna Cheryan. 2017. "Two Axes of Subordination: A New Model of Racial Position." Journal of Personality and Social Psychology 112(5): 696-717. 